

\section{Sumário}

INOVAÇÃO INSTITUCIONAL E RESISTÊNCIA CORPORATIVA: O PROCESSO DE INSTITUCIONALIZAÇÃO E LEgitimaçÃo do Conselho NaCional de JustiçA .............................................................14 Leandro Molhano Ribeiro e Christiane Jalles Paula

A responsabiLIDADE SOCIAL DA MAGISTRATURA BRASILEIRa: ACCOUNTABILITY E RESPONSIVIDADE EM MEIO À TENSÃO ENTRE O DEVER DE PRESTAR CONTAS E A GARANTIA DA INDEPENDÊNCIA JUDICIAL .30

Marcelo Roseno de Oliveira

THE END OF THE WORLD AS THEY KNEW IT: SHOULD FORMER JUDGES BE DENIED ADMISSION TO THE BAR AFTER THE TRANSITION TO DEMOCRACY?

Stefan Kirchner

CONDICIONANTES E DIRETRIZES DE POLÍTICAS PÚBLICAS: UM ENFOQUE COMUNITARISTA DA TRANSFORMAÇÃO SOCIAL

João Pedro Schmidt

GESTÃo PÚBLICA E PARCERIAS PÚBLICO-PRIVADAS: TEORIA DO ESTADO E TECNOLOGIAS DE GOVERNANÇA DIFUSA PARA CONTROLE SOCIAL

Thiago Souza Araujo, Kinn Peduti de Araujo Balesteros da Silva e Aires Jose Rover

A titularidade dos direitos fundamentais por parte de pessoas jurídicas. A empresa COMO AGENTE DE EFETIVAÇÃO DOS DIREIRTOS SOCIAIS: NOTAS INTRODUTÓRIAS AO DIREITO EMPRESARIAL CONSTITUCIONAL 100

Arnaldo Sampaio de Moraes Godoy e Patrícia Perrone Campos Mello

DA TEORIA OBJETIVA DA DESCONSIDERAÇÃO DA PERSONALIDADE JURÍDICA E OS GRUPOS DE SOCIEDADES SOB A ÓTICA DAS RELAÇÕES DE CONSUMO

Daniel Amin Ferraz e Marcus Vinicius Silveira de Sá

A inversão do ônus da prova e a Teoria da Distribuição Dinâmica: SEmelhanças e inCOMPATIBILIDADES 141

Leonardo Roscoe Bessa e Ricardo Rocha Leite 
A ClÁusula de INTERdição de CONCORRÊNCIA NO DIREITO BRASILEIRO E SUA FUNDAMENTAÇÃo histórica: o Caso da Companhia dos Tecidos de Juta (1914). Notas Sobre SEUS Reflexos NORMATIVOS, DOUTRINÁRIOS E JURISPRUDENCIAIS 157

Arnaldo Sampaio de Moraes Godoy e Daniel Amin Ferraz

Conditional cash transfers (CCT) in Latin America: Analyzing their potentials and Challenges special reference to the Argentine Republic 178 Luciano Carlos Rezzoagli, Gonzalo Chiapello e Florencia Cabrera

A CONTRADIÇÃo ENTRE A REgULAMENTAÇÃo EXISTENTE E A COMPLEXIDADE DOS FATOS REAIS NO CASO DAS DROGAS PARA DOENÇAS NEGLIGENCIADAS 194 Marcos Vinício Chein Feres, Lorena Abbas da Silva, Pedro Henrique Oliveira Cuco e Alan Rossi Silva

A efetividade da lei maria da Penha quanto À orientação SEXual........................... 210 Francisco Antonio Morilhe Leonardo

Transexualidade e o "Direito dos banheiros" no STF: uma reflexão À luz de Post, SIEGEL E FraSER ......................................................................................223 Maria Eugenia Bunchaft

ChINA'S NEW CONCEPT OF DEVELOPMENT FROM THE PERSPECTIVE OF THE SUSTAINABLE DEVELOPMENT GOALS...................................................................................245

Di Zhou

CONTAMINAÇÃo MiCrobIológICA dA ÁGUA: PERSPECTIVAS A PARTIR DO DiÁlOGO ENTRE AS FONTES DO DIREITO 260 Patrícia Maino Wartha, Haide Maria Hupffer, Gustavo da Silva Santanna e Fernando Rosado Spilki

Solar panels in Brazil: a FEASible PUblic POLICY 279 Henrique Pissaia de Souza

UNIDADES DE CONSERVAÇÃO, TERRAS INDÍGENAS E QUILOMBOLAS NO ESTADO DO AMAPÁ: COMO DESENVOLVER UM ESTADO CUJO TERRITÓRIO ESTÁ 70\% PROTEGIDO POR LEIS? .290 Linara Oeiras Assunção

A educaÇão diferenciada como política pública de inClusão social dos Guarani e Kaiowá no Estado do Mato Grosso do Sul 310 Isabelle Dias Carneiro Santos 
ESTADO E RELIGIÃO. O DIREITO CONSTITUCIONAL BRASILEIRO E O CRISTIANISMO: INVENTÁRIO DE POSSIBILIDADES ESPECULATIVAS, HISTÓRICAS E INSTRUMENTAIS

Arnaldo Sampaio de Moraes Godoy e Patrícia Perrone Campos Mello

O RiO E A CIDADE: O DiÁlogo JURÍDico ENTRE O PLANO HÍDRICO E O PLANO DIRETOR .........360 Clarissa Ferreira Macedo D'Isep 


\title{
Contaminação microbiológica da água: perspectivas a partir do diálogo entre as fontes do direito*
}

\author{
Microbiological contamination of water: \\ perspectives from the dialogue between \\ sources of law
}

\author{
Patrícia Maino Wartha** \\ Haide Maria Hupffer*** \\ Gustavo da Silva Santanna**** \\ Fernando Rosado Spilki*****
}

\section{Resumo}

O acesso à água potável é um direito fundamental do ser humano que sofre não apenas com a escassez dos recursos hídricos, mas com sua contaminação microbiológica. A todo instante são descobertos novos patógenos contaminantes da água e estes não são suprimidos do consumo, uma vez que a portaria de potabilidade não alcança essas atualizações, ocasionando riscos à saúde. O presente estudo propõe uma análise da Teoria do Diálogo entre as Fontes de Direito e busca compreender se estas podem ser utilizada no Brasil para resolver problemas concretos em relação à regulação sobre patógenos emergentes, uma vez que a legislação brasileira não acompanha a descoberta de novos contaminantes da água para consumo humano. A pesquisa é qualitativa, utiliza o método indutivo com apoio em pesquisa bibliográfica e documental. Os resultados apontam que a resposta pode estar no tempo de defasagem entre o processo legislativo e a descoberta de novos patógenos que contaminam a água para consumo humano. Para solucionar o problema da contaminação microbiológica da água e a flacidez da legislação brasileira em relação aos patógenos emergentes que inviabilizam o consumo humano da água, há de se pensar em novas formas de conferir efetividade a direitos essenciais e constitucionalmente previstos, seja por meio de legislação, de princípios, ou do diálogo entre as fontes do direito sempre preconizando a interdisciplinaridade.

Palavras-chave: Patógenos emergentes. Legislação. Fontes do Direito. Contaminação microbiológica. Água.

*** Programa de Pós-Graduação em Quali-
dade Ambiental. Curso de Graduação em Di-
reito. Universidade Feevale. E-mail: haide@
feevale.br.

**** Curso de Direito. Faculdades Integradas São Judas Tadeu. E-mail: gssantanna@hotmail. com

***** Programa de Pós-Graduação em Qualidade Ambiental. E-mail: fernandors@feevale.br.

\section{Abstract}

Access to safe water is a fundamental human right that suffers not only with the shortage of water resources, but with microbiological contamination. Every moment are discovered new pathogens contaminating the water, and they are not inhibited consumption, since the ordinance potability 
does not reach these updates, causing health risks. This study proposes an analysis of the Dialogue theory between Law sources and whether it can be used in Brazil to solve specific problems in relation to the regulation of emerging pathogens, since Brazilian legislation does not follow the discovery of new contaminants water for human consumption. The research is qualitative, using the inductive method with support for bibliographic and documentary research. The results show that the answer may lie in the time lag between the legislative process and the discovery of new pathogens that contaminate the water for human consumption. To solve the problem of microbiological contamination of water and sagging Brazilian law with respect to emerging pathogens that prevent human consumption of water, one has to think of new ways of giving effect to essential and constitutionally provided rights, either through legislation, principles, or the dialogue between sources of law always recommending interdisciplinarity.

Keywords: Emerging pathogens. Legislation. The right sources. Microbiological contamination. Water.

\section{INTRODUÇÃO}

O acesso à água potável é reconhecido pela Organização das Nações Unidas como um direito fundamental do ser humano. A água, para consumo humano, deve ser potável e segura. Não é mais admissível que, diante do avanço científico da pós-modernidade, ainda ocorram, em grande quantidade, surtos de doenças e mortes relacionados à ingestão de água contaminada. Quando se fala em contaminação microbiológica da água por patógenos emergentes, especialmente aqueles causadores de gastroenterites, não há que se falar apesar de percalços e limitações técnicas no monitoramento e manutenção da qualidade, mas do fracasso das conjunturas regulatórias atuais e, consequentemente, do Direito, e por que não afirmar, do Estado, como um todo.

A resposta pode estar no tempo de defasagem entre o processo legislativo e a descoberta de novos patógenos que contaminam a água para consumo humano. E isso ainda não foi devidamente entendido no Brasil. A regulação deve, impreterivelmente, acompanhar a ciência ou ao menos as tecnologias disponíveis para prevenção de agravos à saúde, que evoluem com o passar dos tempos, e embora se saiba que um tempo de defasagem entre o conhecimento da dinamicidade científica e seu alojamento em lei seja inevitável, a norma necessita se adaptar.

Por outro lado, a lei como fonte única e exclusiva do Direito precisa ser revista. Ou seja, a solução, também, não está, meramente, na criação de novas leis, o que realmente se constata é que a lei não dá conta de toda a problemática que envolve a potabilidade da água, a saúde pública e a preservação ambiental.

Para solucionar o problema da contaminação microbiológica da água e a flacidez da legislação brasileira em relação aos patógenos emergentes que inviabilizam o consumo humano da água, há de se pensar em novas formas de conferir efetividade a direitos essenciais e constitucionalmente previstos, seja por meio de legislação, de princípios, ou do diálogo entre as fontes do direito sempre preconizando a interdisciplinaridade.

Nesse contexto, a hipótese que se lança trata do Diálogo entre as Fontes de Direito como alternativa viável ao caso concreto quando se verificar a descoberta de algum patógeno emergente em água, preconizando harmonização entre realidade e regulação, e se orientados pelos princípios ambientais constitucionais pode ser utilizado no Brasil para resolver problemas concretos em relação à regulação sobre patógenos emergentes, uma vez que a legislação não acompanha a descoberta de novos contaminantes da água para consumo humano.

A partir dessas considerações iniciais, este artigo reflete sobre o que efetivamente deveriam representar as fontes do direito e o processo legislativo e para tanto há de se trazer conceitos basilares e até positivistas para que se introduza e justifique a discussão proposta. 


\section{ContaminaÇÃo microbiológica da ÁGUA POR PATÓgenOS EMERGENTES}

O Programa Mundial de Avaliação dos Recursos Hídricos liderado pela UNESCO publicou em 20 de março de 2015 em Nova Deli (Índia) o "Relatório das Nações Unidas sobre o Desenvolvimento de Água 2015 - Água para um mundo sustentável” em que é, exaustivamente, descrita a precariedade da situação dos recursos hídricos do mundo. Apesar dos inúmeros esforços realizados para ampliar o acesso qualitativo e quantitativo à água, ainda 748 milhões de pessoas no mundo "não têm acesso a fontes de água potável de qualidade"

A qualidade e a potabilidade dos recursos hídricos, frequentemente, estão comprometidas por contaminação microbiológica, sendo que a todo o instante cientistas descobrem novos contaminantes, os chamados patógenos emergentes.

A contaminação microbiológica da água é caracterizada pela presença em corpos hídricos de microrganismos (bactérias, vírus, leveduras ou protozoários) outros que não aqueles naturalmente encontrados no ambiente e oriundos de atividades humanas. São notoriamente importantes os patógenos derivados da excreção fecal, notadamente vírus, bactérias e protozoários causadores de gastroenterites e hepatites em seres humanos. As gastroenterites, doenças caracterizadas por diarreias e vômito, são notadamente importantes em crianças, idosos e indivíduos imunossuprimidos e suas ocorrências estão intimamente ligada ao consumo ou recreação em água contaminada por patógenos. Vírus entéricos e protozoários são geralmente mais resistentes nas matrizes ambientes que bactérias e por isso mais frequentes como causa de agravos à saúde em regiões geográficas com saneamento ambiental deficiente. Ocorre que, paradoxalmente, ao risco estabelecido pelo consumo ou contato com essas águas, utiliza-se para monitorar a presença de contaminação microbiológica de origem fecal apenas bactérias (usualmente coliformes termotolerantes, também denominados fecais): dada a diferença de resistência no ambiente destas em relação a vírus e protozoários, é muito comum que água livre de coliformes apresente massiva contaminação pelos patógenos emergentes citados. Ou seja, trabalha-se com um indicador de contaminação não fidedigno, que permite que passe ao sistema de distribuição água, dita potável (pela legislação), que ainda alberga vírus causadores de diarreias, por exemplo. Tenha-se em mente que grande parte desses patógenos é chamada emergente nesse texto e em outros fóruns por sua real novidade (sempre estiveram presentes) se não pela facilitação de sua detecção em amostras ambientais a partir dos últimos 30 anos.

Os desafios postos pela situação de risco dos recursos hídricos convocam o Direito a posicionar-se em relação a esta ameaça que impacta a saúde humana das gerações presentes e futuras. O caput do art. 225 da Constituição Federal reconhece o direito fundamental a um ambiente ecologicamente equilibrado e a sadia qualidade de vida. Já o caput do art. 170 da CF assegura a todos uma existência digna por meio de prestações positivas. Estes dois dispositivos constitucionais indicam uma clara opção brasileira pelo Estado Socioambiental de Direito. Isso significa que não se pode ignorar que o acesso à água potável é um elemento essencial para uma vida com dignidade e segurança.

Sarlet e Fensterseifer defendem uma dimensão ecológica da dignidade humana "que abrange a ideia em torno de um bem-estar ambiental" para a "concretização da vida humana em níveis dignos. Aquém de tal padrão ecológico, a vida e a dignidade humana estariam sendo violados no seu núcleo-essencial”. Para os autores a segurança ambiental deve "ser reconhecida como elemento integrante do conteúdo normativo do princípio da dignidade da pessoa humana e dos direitos e deveres humanos e fundamentais que lhe são correlatos"2.

1 ORGANIZAÇÃO DAS NAÇÕES UNIDAS PARA A EDUCAÇÃO, A CIÊNCIA E A CULTURA - UNESCO. Gestão mais sustentável da água é urgente. Disponível em: < http://www.unesco.org/new/pt/brasilia/about-this-office/single-view/news/urgent_ need_to_manage_water_more_sustainably_says_un_report/\#.Vh6lUdLwvct>. Acesso em: 14 set. 2016.

2 SARLET, Ingo Wolfgang; FENSTERSEIFER, Tiago. Direito constitucional ambiental: estudos sobre a constituição, os direitos fundamentais e a proteção do ambiente. São Paulo: Revista dos Tribunais, 2011. p. 38-90. 
De modo a evidenciar um cenário complexo para os recursos hídricos impactados severamente pela tecnologia, Narasimhan pontua que a ciência deve contribuir ativamente na elaboração de normas jurídicas sobre água, argumentando que a ciência e o Direito atuam de forma construtiva quando unem esforços a serviço da sociedade. ${ }^{3}$ A questão ecológica põe em causa, radicalmente, a dimensão de legislar para o futuro. Questões como essa traduzem a tensão existente entre ciência e política.

Conforme mencionado anteriormente, a análise da qualidade microbiológica da água visa aferir se há a presença de microrganismos originados de contaminação fecal na água, como forma de prevenir a transmissão de doenças de veiculação hídrica, em especial gastroenterites. Uma pletora de patógenos, incluindo rotavírus, adenovírus, enterovírus, norovírus, Giardia, Cryptosporidium e outros causadores de diarreias (inclusive bactérias) e outras enfermidades podem estar presentes mesmo na ausência dos coliformes fecais ${ }^{4}$.

Pelo art. $3^{\circ}$ e $4^{\circ}$ da Portaria do Ministério da Saúde no 2914 de 12 de dezembro de 2011, toda água destinada ao consumo humano, distribuída coletivamente tanto por meio de sistema e solução alternativa coletiva de abastecimento de água como proveniente de solução alternativa individual, independentemente da forma de acesso da população, deve ser objeto de controle e vigilância da qualidade da água. O inciso II e III do art. $5^{\circ}$ definem água potável aquele que atende "ao padrão de potabilidade estabelecido na Portaria e que não ofereça riscos à saúde" e padrão de potabilidade como o "conjunto de valores permitidos como parâmetro da qualidade da água para consumo humano".

No que diz respeito à fiscalização, a Portaria indica que são as próprias abastecedoras as responsáveis pela fiscalização de seus serviços e estruturação de laboratórios próprios para a realização das análises dos parâmetros de potabilidade, aspecto este muito discutível. Ademais, cabem a elas cabem a elas efetuar o controle das características das suas águas somente encaminhando à autoridade de saúde pública relatórios mensais com informações sobre o controle da qualidade da água e notificando imediatamente a autoridade de saúde pública sempre que houver indícios de risco à saúde ou sempre que amostras coletadas apresentarem resultados em desacordo com os limites ou condições da respectiva classe de enquadramento.

Essa mesma tendência de repassar para as abastecedoras a responsabilidade também é clara no inciso VII, do art. 11 da referida Portaria quando apenas estabelece medidas de análise completa da água em situações emergenciais de "surto de doença diarreica aguda ou outro agravo de transmissão fecal-oral". Esse "poder" das abastecedoras reforça a ideia da flacidez da legislação hídrica brasileira frente ao alarmante quadro de poluição da água, pois somente são tomadas medidas quando o caos se instala. A falta de preventividade da legislação em relação a medidas de prevenção resulta em violação ao direito fundamental à água potável e revela que os princípios constitucionais formadores do Estado Socioambiental de Direito não são observados. Em face disso, há que se indagar: qual a justificativa para arriscar vidas humanas com a previsão de revisão da Portaria a cada 5 anos?

Considerando-se tal preocupação, registra-se que, quando se coloca o termo flacidez, há de se ter em mente que muitos dos parâmetros previstos na legislação atual são de tal modo facilmente atingíveis que nitidamente o conjunto das forças do qual emana a regulação prioriza não a qualidade da água, mas sim a manutenção de um sistema ininterrupto de abastecimento que não cause ônus corporativos e, em última análise, por serem grande parte das companhias de controle de estados e municípios, também políticos. Tal problemática foi cerne do artigo intitulado "A flacidez da legislação brasileira em relação aos patógenos emergentes" que, efetivamente, traz o quão flácida e ineficiente é a portaria de potabilidade da água em não acompanhar os patógenos emergentes, e, pior ainda, inclusive os contaminantes já conhecidos sequer são contemplados 5 .

3 NARASIMHAN, T. N. Water, law, science. Journal of bydrology. Science Direct. Department of Materials Science and Engineering, and Department of Environmental Science, Policy and Management, University of California at Berkeley, p. 125-138, out. 2007. 4 HUPFFER, Haide Maria et al. A flacidez da legislação brasileira em relação aos patógenos emergentes. Revista de direito ambiental, v. 69, p. $315-342$, jan./mar. 2013.

5 HUPFFER, Haide Maria et al. A flacidez da legislação brasileira em relação aos patógenos emergentes. Revista de direito ambiental, 
A discussão sobre a flacidez da legislação brasileira em relação a patógenos emergentes implica, também, o enfrentamento de outra questão: a morosidade do processo legislativo e a utilização da lei como fonte exclusiva do Direito.

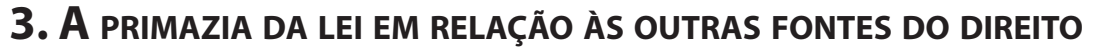

Tratar de fontes do direito e do processo legislativo é algo basilar no ordenamento jurídico, contudo quando as complexidades se aglomeram em torno de ineficiências essenciais, básicas e fundamentais como no caso da contaminação microbiológica da água para consumo humano, o retorno às bases faz-se imperativo.

Literalmente, Bobbio refere que “'fontes do direito' são aqueles fatos e aqueles atos dos quais o ordenamento jurídico faz depender a produção de normas jurídicas". A lei, a analogia, o costume, a jurisprudência e os princípios gerais do Direito e a doutrina são consideradas fontes do Direito. Entretanto, para o positivismo jurídico, somente a lei, considerada lato sensu, pode oferecer critérios mais racionais que a jurisprudência, os costumes ou os precedentes.

Ao assumir que o Direito se resume a um conjunto determinado e hierárquico de normas objetivamente determinadas por atos do Legislativo e consolidadas em prescrições formais normativas, o positivismo jurídico ostenta como dogma a lei como fonte principal do Direito. Ao poder Judiciário é delegado um poder secundário e extremamente conservador: ele é, portanto, o transmissor de um corpo de regras exegético-normativas, só podendo recorrer a outras fontes por expressa autorização legal, tratando assim as demais fontes como acessórias.

Por essa razão, "no Brasil e na quase totalidade dos países modernos, a fonte principal do direito é a lei que brota do processo legislativo em parlamentos laicos e escolhidos pela comunidade". ${ }^{7}$ Essa postura assegura, fortalece e sedimenta a alienação dos juristas em reação aos problemas sociais e políticos de seu tempo, contribuindo para mantê-los na servil condição de executores da lei do Estado, "seres iluminados", proferindo sentença com sentido unívoco, produto de um juízo de certeza, representando a única solução da moldura da norma, resultando, enfim, na submissão do juiz ao poder político. ${ }^{8}$ Embora a suposta laicidade (apenas como figura de linguagem, para além da religião) torna-se discutível, uma vez que o parlamento "deveria" produzir legislação em atenção a demandas e a pressões da sociedade, incluindo gestores públicos e porque não, federações de companhias de abastecimento, academia e outras.

A respeito da identificação do Direito com a ordem legal vigente, Streck fala de uma crise de comprometimento, pois “obedece-se à lei, mas não se obedece à lei das leis [...]!" ${ }^{9}$. Essa postura, para o autor, reflete que a lei assume a titularidade e a exclusividade das fontes do direito o que resulta na ineficiência que se vislumbra, ignorando-se inclusive a própria Constituição Federal. $\mathrm{O}$ autor discorre que o novo constitucionalismo exige uma "nova teoria das fontes", uma "nova teoria da norma" e um novo "modo de compreender o Direito". Para tanto, torna-se imperativo desmistificar que "a lei é a única fonte", ignorando que a própria "Constituição é a nova fonte", e o credo "no mundo ficcional das regras, ignorando que a (velha) teoria da norma necessita recepcionar a era dos princípios, que, fundamentalmente, introduzem no Direito a realidade escamoteada historicamente pelo mundo das regras do positivismo"10.

v. 69 , p. $315-342$, jan./mar. 2013.

6 BOBBIO, Norberto. Teoria do ordenamento jurídico. São Paulo: Edipro, 2011. p. 58.

7 CARVALHO, José Maurício. Miguel Reale: ética e filosofia do direito. Porto Alegre: EDIPUCRS, 2011. p. 177.

8 SILVA, Ovídio Araújo Baptista da. Jurisdição e execução na tradição romano-canônica. 2. ed. São Paulo: Revista dos Tribunais, 1997. p. 105-197.

9 STRECK, Lenio Luiz. Verdade e consenso: constituição, hermenêutica e teorias discursivas: da possibilidade à necessidade de respostas corretas no direito. 3. ed. Rio de Janeiro: Lumen Juris, 2009. p. 198-210.

10 STRECK, Lenio Luiz. Devemos nos importar, sim, com o que a doutrina diæ? 2006. Disponível em: < http:/ /www.conjur.com.br/2006- 
A lei é (apenas) uma das fontes do direito que tem por intuito impor regras gerais de conduta ${ }^{11}$. Com a implantação do Estado Democrático de Direito a Constituição adquire papel central no ordenamento jurídico. Tanto a lei quanto as demais fontes, como os princípios, a analogia e os costumes, assumem papel meramente secundário. A Lei, contudo, em razão de sua origem democrática (legislativo) continua(va) sendo o local de aposta de transformação social. Porém, a perda de credibilidade no legislador ${ }^{12}$ e a hipertrofia legislativa somada à falta de efetividade ${ }^{13}$, levam(ram) ao declínio da lei enquanto fonte. Por mais paradoxal que seja, não obstante a inflação legislativa, ainda existem determinadas áreas que permanecem em uma obscuridade legal: é o caso dos patógenos emergentes contaminantes da água,

Consoante o artigo $6^{\circ}$ da Declaração dos Direitos do Homem e do Cidadão de 1789 "A lei é a expressão da vontade geral. Todos os cidadãos têm direito a concorrer pessoalmente, ou por seus representantes, para sua formação". A lei de introdução às normas do direito brasileiro, em seu artigo $3^{\circ}$ disciplina a obrigatoriedade da lei, ao discorrer que "Ninguém se escusa de cumprir a lei, alegando que não a conhece". No mesmo sentido, o mesmo diploma legal, refere em seu artigo $4^{\circ}$ que o julgador decidirá o caso em conformidade à lei e quando essa for "omissa", "de acordo com a analogia, os costumes e os princípios gerais de direito", admitindo-se, pois, a discricionariedade do intérprete.

Em suas considerações, Streck denuncia que para muitos "interpretar a lei é retirar da norma tudo o que ela contém"(sic), como se o processo hermenêutico fosse uma “lipoaspiração epistemológica", sendo que não está autorizado pelo processo hermenêutico quaisquer "atribuições arbitrárias ou segundo a vontade e o conhecimento do intérprete”. O fato é que “o legislativo (a lei) não pode antever todas as hipóteses de aplicação,não significa uma queda na irracionalidadee nem uma delegação em favor de decisionismos”"14.

Por isso é razoável afirmar que sistema vigorante é ineficaz ao caso concreto uma vez que é eivado de discricionariedade sem quaisquer critérios, possibilitando ao aplicador, interprete e julgador fazer uso de múltiplas e distintas formas com base no mesmo dispositivo, ou melhor, na mesma fonte de direito (lei), ou a pretexto da subjetividade na interpretação ou sob a justificativa das "lacunas" no ordenamento. É exatamente essa prática que gera insegurança e insucesso às regulações, como no acompanhamento aos microrganismos contaminantes da água.

Em verdade, é exatamente o que é flagrado quando grande parte das questões ambientais é tratada por regulamentações expedidas por órgãos do executivo brasileiro, fazendo às vezes de "legisladores". Essa constatação sustenta que no Brasil, observa-se a práxis do Poder executivo agindo de forma a proteger-se da fiscalização do considerado "coadjuvante" Poder Legislativo, sobretudo percorrendo, livremente, o fértil terreno legislativo, dentro e fora de qualquer limite estabelecido, "em alguns momentos pela força das armas, impondo regras de forma arbitrária, e em outros, pela força das maiorias, operando à margem dos textos constitucionais e beneficiando-se da aquiescência ou da resignação do legislativo"15.

Dworkin refere, exatamente, que o direito, simplesmente, é o que "as instituições jurídicas, como as legislaturas, as câmaras municipais e os tribunais, decidiram no passado", retratando, pois, o processo legislativo, e que a divergência entre os intérpretes, julgadores e advogados, advém da discordância do que o

jan-05/devemos_importar_sim_doutrina>. Acesso em: 19 set. 2016. p. 01.

11 "No huelga recorder que el Estado de Derecho tenía como uno de sus valores jurídicos prioritarios la supremacía de la ley. Heredo ideológico de las aspiraciones del iluminismo jurídico, el Estado de Derecho consideraba la garantía de la generalidad como un elemento constitutivo de la ley y como un fundamento de su primacía en cuanto fuente jurídica.” PÉREZ LUÑO, Antonio Henrique. El desdobramiento de las fuentes del derecho. Madrid: La Ley, 2011. p. 110.

12 BINENBOJM, Gustavo. Uma teoria do direito administrativo: direitos fundamentais, democracia e consitucionalização. 2. ed. Rio de Janeiro: Renovar, 2008. p. 125.

13 "La ley, en suma, ya no es garantía absoluta y última de estabilidad, sino que ella misma se convierte en instrument y causa de inestabilidad." ZAGREBELSKY, Gustavo. El derecho dúctil: ley, derechos, justicia. Madrid: Editorial Trotta, 2009. p. 38.

14 STRECK, Lenio Luiz. Devemos nos importar, sim, com o que a doutrina diz? 2006. Disponível em: <http://www.conjur.com.br/2006jan-05/devemos_importar_sim_doutrina>. Acesso em: 19 set. 2016. p. 03.

15 PESSANHA, Charles. O poder executivo e o processo legislativo nas constituições brasileiras: teoria e prática. In: VIANA, Luiz Werneck. A democracia e os três poderes no Brasil. Rio de Janeiro: IUPERJ/FAPERJ, 2002. p. 180. 
direito “deveria ser" e não do que realmente é. Assim, afirma que "a divergência teórica é uma ilusão, que na verdade os advogados e juízes estarão de acordo quanto aos fundamentos da lei"”.

Dworkin relata, ainda, que nos Estados Unidos e na Grã Bretanha a opinião popular profere que os juízes devem cumprir o direito "ao invés de tentar aperfeiçoá-lo", no entanto o autor atenta que alguns juízes não aceitam tal "submissão", submetendo a lei a seus objetivos ou opiniões políticas. "São estes os maus juízes, os usurpadores, os destruidores da democracia", profere. Em contrapartida, alguns populares, minoritariamente, entendem o oposto, que, “o mau juiz é o juiz rígido e 'mecânico', que faz cumprir a lei, sem se preocupar com o sofrimento, a injustiça ou a ineficiência que segue. O bom juiz prefere a justiça à lei”"17.

Gadamer, por sua vez, refere que "A lei é sempre deficiente, não porque o seja por si mesma, mas porque frente ao ordenamento a que intencionam as leis, a realidade humana é sempre deficiente e não permite uma aplicação simples das mesmas"18, e uma das razões apontadas seria a de que "não existe uma determinação prévia daquilo em que a vida no seu todo está orientada" ${ }^{\prime 1}$.

Essa visão patológica do Direito ancorado no império da lei é sustentada por posturas positivistas de um pensamento jurídico objetificador em que predomina um excessivo formalismo e procedimentalismo, como uma espécie de porto seguro que possibilita alcançar a "vontade da norma, o espírito do legislador e o unívoco sentido do texto" 20 , resultando na objetificação da interpretação. Qualquer diagnóstico mostrará que a crise da operacionalidade do Direito Ambiental expõe suas insuficiências por não se afastar do modelo de Direito sustentado por normas, que se consolida pela negação à abertura propiciada pelos princípios constitucionais ambientais que objetivam evitar a discricionariedade judicial, além de outras tantas insuficiências que tornou o Poder Legislativo refém de interesses econômicos e políticos.

\section{A (IM)POSSIBILIDADE DE LEGISLAR SOBRE O FUTURO}

O processo legislativo representa um dos mais relevantes "elementos de representatividade dentro de uma sociedade que se descreve como constitucional, isto é, dentro de um Estado de Direito onde as constituições assumem um papel de conservação dos direitos fundamentais e da ordem estabelecida como sinais democráticos", como observa Luz.? Para o autor, inobstante e inevitavelmente, o processo legislativo também "engloba o conjunto de fatores reais ou fáticos que põem em movimento os legisladores", sendo que tais procedimentos ou fatores incluem "o modo de proceder ao realizar a tarefa legislativa, sua influência sobre determinados projetos de lei, a opinião pública, as crises sociais, as pressões de grupos organizados, lobbying, os acordos de partidos, as compensações políticas, a composição partidária ou social da assembleia, além da troca de votos [...]"21. É possível antever que "a opinião pública" que "deveria" ser levada em consideração no processo legislativo, somente o é quando resulta em "acordos, favores e votos”, ou seja, quando houver interesses envolvidos.

No caso em exame (contaminação da água por microrganismos patogênicos) e no que se refere ao processo legislativo, objetivamente tratando, para que, então, se constate as razões do tempo de defasagem entre a atualização da lei e a descoberta científica, no caso, os patógenos emergentes contaminante da água,

16 DWORKIN, Ronald. O império do direito. São Paulo: M. Fontes, 1999. p.10-11.

17 DWORKIN, Ronald. O império do direito. São Paulo: M. Fontes, 1999. p.11.

18 GADAMER, Hans-Georg. Verdade e método: traços fundamentais de uma hermenêutica filosófica. 3. ed. Petrópolis: Vozes, 1999. p. 474.

19 GADAMER, Hans-Georg. Verdade e método: traços fundamentais de uma hermenêutica filosófica. 3. ed. Petrópolis, RJ: Vozes, 1999. p. 477.

20 STRECK, Lenio Luiz. Da interpretação de textos à concretização de direitos: o desafio da hermenêutica comprometida com o Estado Democrático de Direito. Revista Latino-americana de Estudos Constitucionais, v. 6, jul./dez. 2015. p. 575.

21 LUZ, Cícero Krupp da. Governança, déficit democrático e processo legislativo europeu. Revista Direitos Culturais, Santo Ângelo, v. 8 , n. 16,2013 . p. 10. 
contempla conjunto de atos que consistem em iniciativa, discussão, emenda, votação, sanção e veto, promulgação e publicação, praticados pelos órgãos competentes na produção das leis e outras espécies normativas indicadas diretamente pela Constituição ${ }^{22}$. Evidencie-se: sem qualquer discussão com a sociedade, que seria a titular do poder, apenas representada pelo poder legislativo e o processo que o compreende, e menos ainda citam qualquer menção, consulta ou inspiração no conhecimento produzido pela pesquisa e tecnologia ou por órgãos técnicos com conhecimentos específicos e científicos da matéria objeto de regulação, ou seja, o processo legislativo compreende fases titularizadas unicamente pelos poderes legislativo e executivo, o que talvez desde o princípio denote a razão de sua ineficiência.

Todavia, além do processo legislativo apresentar um tempo de defasagem (no caso brasileiro, gigantesco) entre a descoberta científica e a regulação, também se depara quanto à (im)possibilidade de se legislar sobre o futuro. Dessa feita talvez outra fonte do direito, que não a lei propriamente dita, pudesse dar conta da complexidade dessa tarefa: acompanhar os avanços científicos às vistas da concretização de direitos constitucionalmente previstos, ou quem sabe o diálogo entre as fontes, a exemplo legislação e princípios.

A esse respeito, outro problema enfrentado é que fatores econômicos gerem mais harmonização social do que a própria legislação, uma vez que, por vezes, a lei representa mero temor aos riscos de sanções que se seguem a partir da violação da mesma, mas o que efetivamente traz inovações é o caráter/interesse econômico. Talvez aqui se a atualização dos parâmetros de potabilidade trouxesse algum interesse econômico aos poderes legislativo e executivo, quem sabe essas fases que compõem o processo legislativo, se tornariam mais eficientes e acompanhariam os patógenos emergentes contaminantes, ou quem sabe o tempo de atualização seria menos delongado.

Assim e embora se saiba que não é exatamente com o propósito representativo que o poder legislativo opere, instaura-se "uma ideia de representação que está intimamente ligada à separação de poderes"23. A partir de então, é possível antever as falhas estruturais ou procedimentais do processo legislativo, que denotam a subjetividade, parcialidade e fragmentação/isolamento do processo em si.

Da mesma forma, ocorre quanto à atualização da legislação, se é que o termo "atualização" pode literalmente ser empregado frente à evidente dicotomia entre efetividade e atualização normativa, ou seja, entre lei e realidade, haja vista que, sem atualização, a legislação torna-se ineficaz, como flagrado constantemente e apontado no caso específico da flacidez da legislação presente quanto à qualidade da água de consumo quando cientificamente são encontrados novos patógenos contaminantes, os quais deveriam ser, imediatamente, inseridos na regulação específica para que constassem nos indicadores de potabilidade.

Em se tratando de processo legislativo internacional, discorre Luz, caracterizando-o como a "forma na qual instituições normativas são consolidadas no seio da ordem global, tradicionalmente por meio de tratados internacionais realizados por Estados soberanos". O autor traz como exemplo o Parlamento Europeu, como sendo o único órgão da União Europeia que resulta de eleições diretas desde 1979, fazendo dele "único": "o Parlamento Europeu, tem um verdadeiro poder legislativo, que desenvolve e aprova leis diretamente, embora não tenha poderes de soberania como um parlamento nacional, porque ele é um colegislador" ${ }^{24}$. Profere que atualmente é "o modelo mais avançado de parlamento de integração existente"

Na União Europeia, o art. 26 da Directiva 98/83/CE do Conselho de 3 de Novembro de 1998 não impõe limites aceitáveis e só aceita a ausência absoluta de "microrganismos, parasitas ou quaisquer substâncias em quantidades ou concentrações que constituam um perigo potencial para a saúde humana" para consi-

22 LUZ, Cícero Krupp da. Governança, déficit democrático e processo legislativo europeu. Revista Direitos Culturais, Santo Ângelo, v. 8, n. 16, 2013. p. 11.

23 LUZ, Cícero Krupp da. Governança, déficit democrático e processo legislativo europeu. Revista Direitos Culturais, Santo Ângelo, v. 8 , n. 16,2013 . p. 12.

24 LUZ, Cícero Krupp da. Governança, déficit democrático e processo legislativo europeu. Revista Direitos Culturais, Santo Ângelo, v. 8, n. 16, 2013. p. 12.

25 LUZ, Cícero Krupp da. Governança, déficit democrático e processo legislativo europeu. Revista Direitos Culturais, Santo Ângelo, v. 8, n. 16, 2013. p. 11. 
derar a água limpa e salubre para consumo humano, bem ao contrário da legislação brasileira. Se observado a contaminação da água na União Europeia o fornecimento dessa água deve ser proibido ou sua utilização restringida. Já no Brasil, as providências a serem tomadas ficam à cargo da discricionariedade administrativa da autoridade de saúde pública competente.

Outro exemplo é a Directiva 2003/35/CE do Parlamento Europeu e do Conselho de 26 de maio de 2003 que estabelece que os Estados-Membros devem assegurar a participação do público na elaboração de planos e programas relativos ao meio ambiente, contribuindo assim para a implementação das obrigações decorrentes da Convenção de Aarhus de 2001 (Convenção sobre o Acesso à Informação, Participação Pública na Tomada de Decisões e Acesso à Justiça). A Directiva 2003/35/CE no art. 2, inciso 2, alínea b disciplina que: "b) O público tenha o direito de exprimir as suas observações e opiniões, quando estão abertas todas as opções, antes de serem tomadas decisões sobre os planos e programas; c) Ao tomar decisões sobre os planos e programas, sejam devidamente tidos em consideração os resultados da participação do público" ${ }^{26}$.

Embora não se possa realizar propriamente um comparativo entre o Poder Legislativo brasileiro e da União Europeia, é pertinente tratar de uma essencial diferença: no Brasil os parlamentos não estão abertos/ acessíveis à sociedade, como na Europa, o que justificaria a ineficiência e morosidade, além é claro de nossa democracia "representativa", representar unicamente os interesses dos próprios parlamentares e não da população que os elegeu. Explica Luz, ainda a respeito da experiência europeia, que, mesmo sendo forte e amplo, é compartilhado entre o Conselho da União Europeia e o Parlamento Europeu. Nessa sistemática, a elaboração das leis europeias diretivas e regulamentos é distribuída conforme a competência de cada órgão, que tem a possibilidade de aprovar, alterar ou rejeitar o conteúdo das leis europeias. Dois terços das leis europeias são adotadas, conjuntamente, pelo Parlamento Europeu e pelo Conselho ${ }^{27}$.

Erik Jayme, idealizador da Teoria do Diálogo entre as Fontes no Direito Internacional Privado, pontua que a União Europeia assume "como tarefa principal da ciência descobrir, conceituar e daí criar um direito privado europeu”. Nesse contexto, sobressai na cultura jurídica europeia o fato da mesma retornar "às mentes com a ajuda do direito comparado" o que para o autor representa "um instrumento, uma nova guia, uma nova 'diretiva de interpretação' (Interpretation directive)" 28 .

O fato é que, por meio de uma delegação por áreas de competência, torna-se muito mais eficiente o processo legislativo tanto do ponto de vista prático, adaptando-se ao caso concreto, quanto do ponto de vista objetivo, desvencilhando-se de interesses aquém à finalidade pública.

Luz, ainda e por derradeiro, trata da necessidade de criação de "conceito de bens públicos globais" "pois, de outra forma, a democratização e a participação de novos atores não levaria em conta coletividades, apenas objetivos e interesses individuais" ${ }^{29}$. Em relação a esse contexto, Santos aduz que um dos modos de produção da globalização são as lutas transnacionais pela proteção de recursos e serviços ambientais considerados patrimônio comum da humanidade e que são essências para a sobrevivência digna do ser humano, "cuja sustentabilidade só pode ser garantida em escala planetária". Pela sua natureza, os recursos ambientais devem ser geridos por outra lógica e concebidos como patrimônio comum da humanidade em nome da equidade intergeracional o que certamente exige uma responsabilidade alargada à escala universal ${ }^{30}$.

Nesse cenário internacional, a própria Agência Nacional de Águas (ANA) reconhece que "Diretrizes internacionais de qualidade da água podem auxiliar no estabelecimento de níveis de proteção padronizados

26 UNIÃO EUROPEIA. Directiva 2003/35/CE no art. 2, inciso 2.

27 LUZ, Cícero Krupp da. Governança, déficit democrático e processo legislativo europeu. Revista Direitos Culturais, Santo Ângelo, v. 8, n. 16, 2013. p. 12.

28 JAYME, Erik. Visões para uma Teoria Pós-Moderna do Direito Comparado. Revista dos Tribunais, v. 759, p. 24, jan. 1999.

29 LUZ, Cícero Krupp da. Governança, déficit democrático e processo legislativo europeu. Revista Direitos Culturais, Santo Ângelo, v. 8, n. 16, p. 14, 2013.

30 SANTOS, Boaventura de Souza. Linha do Horizonte. In: SANTOS, Boaventura de Souza (Org.). A Globalizaçãa e as Ciências Sociais. 2. ed. São Paulo: Cortez, 2002. p. 70. 
referentes à saúde humana e ambiental relacionados à água em todos os países e ajudar na elaboração de normas viáveis de qualidade da água" 31 . Isto posto, a observação ao processo legislativo internacional faz pleno sentido por seu significado na garantia de formas democráticas de produção legislativa, bem como pelo compromisso com os bens públicos globais ${ }^{32}$, o que deveras não ocorre no cenário brasileiro.

Assim, a atualização caminha juntamente da regulação, tanto em situações genéricas quanto para o que se propõe o presente estudo: obtenção de água própria para o consumo humano. E nesse anseio por solucionar o problema da flacidez da legislação/regulação brasileira em relação aos patógenos emergentes que inviabilizam o consumo humano da água, há de se pensar em novas formas de conferir efetividade a direitos essenciais, sendo elementar referir que o meio ambiente é imprescindível não apenas à existência humana como à vida, desta feita, assim como os princípios basilares de nosso ordenamento, a preservação ambiental e a saúde pública estão previstas em nossa Constituição, considerada o imperativo regulatório em nosso ordenamento.

A partir do exposto, tornou-se perceptível que o tempo de defasagem entre o processo legislativo e a descoberta de novos patógenos que contaminam a água para consumo humano carece de solução. E, por isso, é coerente utilizar o diálogo entre as fontes de Direito quando se descobrirem novos microrganismos contaminantes da água já que atentam à vida, até que os novos parâmetros sejam atualizados na regulamentação normativa específica, compactuando dessa feita com a igualdade das fontes do direito, onde princípio e legislação caminhem juntos para a concretização de direitos e em especial para perpetuação da vida. Além do diálogo entre as fontes do Direito, revela-se indubitável a interdisciplinariedade, perfazendo esse diálogo entre ciência, direito, tecnologia e Estado, uma vez que atualmente o que se observa é a falta de coesão entre academia, sistema legislativo, político e jurídico.

\section{Diálogo ENTRE AS FonTES do diREITO NA QUESTÃo dOS PATÓgenOS EMERGENTES}

Em vista da necessidade de adaptar os avanços científicos às formas de regulação da sociedade (fontes do direito) é que o diálogo entre as fontes do direito pode representar uma viável, e talvez única, alternativa de harmonização entre realidade e regulação, promovendo uma "revolução no Direito". Esse se revela o desafio diante da flacidez da regulação frente aos patógenos emergentes contaminantes da água.

No último século, houve uma renovação no plano da teoria das fontes do direito. Hoje é reconhecido o papel da jurisprudência, da historicidade do direito, das convenções internacionais e dos princípios gerais do direito. A Teoria das Fontes de direito ressurge para garantir que o direito não pode ser concebido apenas sob o mito da exclusividade da lei.

Engelmann explica o diálogo das Fontes, representando o próprio “diálogo entre leis postas, podendo, também, envolver normas narrativas de inspiração, costumes, princípios gerais, reconhecendo a força dos princípios imanentes do sistema e do bloco de constitucionalidade", trabalhando simultaneamente a aplicação das diversas e distintas fontes legislativas. Sintetiza que "as fontes do direito dialogando entre si contribuirão com respostas jurídicas frente ao atual déficit legislativo" "33, a exemplo do que ocorre com a regulação dos patógenos emergentes contaminantes da água, uma vez que a descoberta de um novo contaminante não resulta em consequente e urgente atualização da portaria de potabilidade.

31 AGÊNCIA NACIONAL DE ÁGUAS. Programa das Nações Unidas para o Meio Ambiente. Cuidando das águas: soluções para melhorar a qualidade dos recursos hídricos. Brasília: ANA, 2011. p. 83.

32 LUZ, Cícero Krupp da. Governança, déficit democrático e processo legislativo europeu. Revista Direitos Culturais, Santo Ângelo, v. 8, n. 16, 2013. p. 15.

33 ENGELMANN, Wilson; HOHENDORFF, Raquel Von. De Eric Drexler a Erik Jayme: as respostas que o direito (ainda não) tem para a questão das nanotecnologias. In: ROVER, Aires Josér; SIMÃO FILHO, Adalberto; PINHEIRO, Rosalice Fidalgo (Org.).

Direito e Novas Tecnologias. Florianópolis: FUNJAB, 2013. v. 1. p. 385-386. 
Nessa esteira, com o diálogo entre as fontes essa atualização da regulação que estabelece a parametrização da potabilidade da água, ou seja, esse acompanhamento às novas descobertas científicas sobre novos contaminantes microbiológicos na água poderia acontecer, convergindo legislação e princípios, por exemplo.

A defesa pela adoção da Teoria do Diálogo entre as Fontes do Direito acompanha o dizer de Engelmann de que a "estrutura do sistema jurídico não responde adequadamente aos desafios que eles estão lançando, exigindo a revisão da estrutura e concepção das fontes do Direito" 34 . E eis aqui o ponto crucial do presente estudo, apontando a necessidade de reestruturação das fontes do direito, ou seja, modificações estruturais, para que haja sintonia entre realidade e regulação (atualização das novas descobertas científicas, que no caso de patógenos emergentes, atentem contra a água para consumo humano).

Amaral Júnior observa que foi Jayme quem denominou a aplicação coordenada e simultânea das fontes legislativas convergentes de "diálogo das fontes", ou seja, a teoria do diálogo das fontes foi desenvolvida por Erik Jayme, na Alemanha. Nesse sentido, sinaliza para uma nova forma de encarar a coexistência das normas. "A eliminação da norma incompatível não é abandonada, mas é uma via extrema a ser usada quando todos os outros recursos falharam" $"$.

Engelmann propõe a revisão da "estrutura das fontes do Direito, saindo de um cenário onde as fontes são analisadas individualmente, para uma valoração conjunta e complementar" ${ }^{\text {"36 }}$ ou seja, propondo o diálogo entre as fontes. Esse diálogo, na perspectiva de Marques, propõe evitar-se a "antinomia", conflitos de convergência na aplicação em caso concreto de duas normas, buscando, pois, soluções plurais ${ }^{37}$. Para Erik Jayme, o pluralismo, que caracteriza a cultura pós-moderna no direito, "manifesta-se na multiplicidade de fontes legislativas a regular o mesmo fato, com a descodificação ou a implosão dos sistemas genéricos normativos ('Zersplieterung')", manifestando-se no pluralismo de sujeitos ${ }^{38}$.

Preconizando essa "(re)estruturação das fontes do Direito", Engelmann enfatiza que se viabiliza "uma abertura do sistema jurídico para a efetiva valorização do ser humano e do meio ambiente[...] retirando a estrutura hierárquica das fontes do Direito" 39 propondo, pois, o diálogo entre as fontes, ou seja focando-se em uma horizontalização com "passagem obrigatória pela Constituição" 40.

Como observado no item anterior, que trata das fontes do direito e do processo legislativo, a hierarquização das fontes é paradigma vigorante que coloca a lei no topo da pirâmide, como se a legislação em si desse conta de todas as complexidades atinentes ao ordenamento jurídico.

Portanto, frente ao insucesso da hierarquização das fontes do Direito, propõe-se a sua horizontalidade: "No lugar da verticalização do escalonamento piramidal das fontes será instalada uma disposição horizontal

34 ENGELMANN, Wilson. As nanotecnologias e os novos direitos: a (necessária) revisão da estrutura das fontes do direito. In: ANUÁRIO DE DERECHO CONSTITUCIONAL LATINOAMERICANO. 17., 2011, Montevideo. p. 383-396. Disponível em: <http://www.juridicas.unam.mx/publica/librev/rev/dconstla/cont/2011/pr/pr25.pdf>. Acesso em: 30 set. 2016.

35 AMARAL JÚNIOR, Alberto do. O Diálogo das fontes: fragmentação e coerência no direito internacional contemporâneo. Anuário Brasileiro de Direito Internacional, v. 2, 2008. p. 17.

36 ENGELMANN, Wilson. As nanotecnologias e os novos direitos: a (necessária) revisão da estrutura das fontes do direito. In: ANUÁRIO DE DERECHO CONSTITUCIONAL LATINOAMERICANO. 17., 2011, Montevideo. p. 383-396. Disponível em: <http://www.juridicas.unam.mx/publica/librev/rev/dconstla/cont/2011/pr/pr25.pdf>. Acesso em: 30 set. 2016 . p. 384.

37 MARQUES, Cláudia Lima. Superação das antinomias pelo diálogo das fontes: o modelo brasileiro de coexistência entre o código de defesa do consumidor e o código civil de 2002. Revista Da ESMESE, Aracajú, n. 7, 2004. p. 42.

38 JAYME, Erik. Identité culturelle et intégration: le droit international privé postmoderne. Recueil des Cours de l'Académie de Droit International de la Haye, II, Kluwer. Haia, 1995. p. 36.

39 ENGELMANN, Wilson. As nanotecnologias e os novos direitos: a (necessária) revisão da estrutura das fontes do direito. In: ANUÁRIO DE DERECHO CONSTITUCIONAL LATINOAMERICANO. 17., 2011, Montevideo. p. 383-396. Disponível em: <http://www.juridicas.unam.mx/publica/librev/rev/dconstla/cont/2011/pr/pr25.pdf>. Acesso em: 30 set. 2016.

40 ENGELMANN, Wilson. As nanotecnologias e os novos direitos: a (necessária) revisão da estrutura das fontes do direito. In: ANUÁRIO DE DERECHO CONSTITUCIONAL LATINOAMERICANO. 17., 2011, Montevideo. p. 383-396. Disponível em: <http://www.juridicas.unam.mx/publica/librev/rev/dconstla/cont/2011/pr/pr25.pdf>. Acesso em: 30 set. 2016. 
de todas elas, potencializando o diálogo e resposta articulada constitucionalmente" ${ }^{41}$, ou seja, o diálogo entre as fontes que tentam "vencer o filtro constitucional".

Nesse trilhar, Mazzuoli e Teixeira, trazem o exemplo norte-americano, ao mencionar que em defesa dos direitos fundamentais e humanos, que perpassam por um fenômeno denominado "greening" (esverdeamento em uma tradução literal, remetendo a uma visão conservacionista do ambiente) às vistas da introdução da preservação ambiental como intrínseco à defesa dos direitos fundamentais, em nenhum momento os sistemas de proteção "rivalizam com a jurisdição estatal" na "proteção de forma mais célere e efetiva dos direitos fundamentais" ${ }^{42}$. Quando se trata de água segura para consumo humano não pode pairar qualquer dúvida a esse respeito e não se pode deixar a solução a critério da discricionariedade do órgão público ou das abastecedoras. Quem está preso ao paradigma da lei como única e exclusiva fonte do Direito é incapaz de perceber as limitações textuais do sistema de normas quando confrontado com a realização do direito fundamental à água potável e segura.

A partir de exemplos concretos (Convenção Americana e as normas dos tratados internacionais e do direito interno), Mazzuoli e Teixeira preconizam o diálogo entre as fontes às vistas da aplicação da norma mais benéfica ao ser humano ${ }^{43}$, e então intrinsecamente está contido o meio ambiente, ou seja, trata-se de utilizar o diálogo entre as fontes para fazer uso "da melhor norma a ser utilizada no caso concreto" 44 , o que seria viável no caso em pauta agregando princípios ambientais e regulação específica para concretizar a constituição no sentido de proporcionar aos cidadãos água potável.

Tal aplicação demonstra não apenas o diálogo entre as fontes como entre o sistema em si, uma vez que possuem o mesmo propósito. Eis a pergunta ao caso da contaminação microbiológica da água por patógenos emergentes no Brasil, todos possuem os mesmos propósitos, ou seria mais adequado denominar de interesses?

Água segura para consumo humano é por definição primária, água sem contaminação microbiológica, contaminantes radiológicos e substâncias químicas. Embora com atraso, em 2010 a Assembleia Geral da Organização das Nações Unidas (ONU) pela Diretiva n 64/292 reconheceu o direito à água potável e ao saneamento básico como um direito humano fundamental e essencial para a sadia qualidade de vida e de todos os direitos humanos. O Brasil, como país signatário de pactos de direitos internacionais, tem como obrigação criar as condições para realizar em seu território o direito fundamental à água potável. Uma das formas de realização desse compromisso se dá pelo Diálogo entre as Fontes de Direito quando se está diante de um novo patógeno contaminante na água para consumo.

Para tanto, Mazzuoli e Teixeira asseveram que esse "diálogo deve ocorrer entre as normas de direito interno e internacional", embora concluam que no Brasil esse acontecer ainda está em "estágio aquém da maturidade" 45 . Entretanto, é essa funcionalidade do Direito que a sociedade espera e reivindica ao necessitar de regulação prática desde as necessidades mais básicas, como água potável, às mais complexas, contudo essa não é uma tarefa simples e isolada, e menos ainda, quando se burocratiza e hierarquiza as próprias fontes reguladoras.

Supiot trata do "declínio das leis", em primeira análise, discorrendo que "é o diagnóstico geralmente

41 ENGELMANN, Wilson. As nanotecnologias e os novos direitos: a (necessária) revisão da estrutura das fontes do direito. In: ANUÁRIO DE DERECHO CONSTITUCIONAL LATINOAMERICANO. 17., 2011, Montevideo. p. 383-396. Disponível em: <http://www.juridicas.unam.mx/publica/librev/rev/dconstla/cont/2011/pr/pr25.pdf>. Acesso em: 30 set. 2016.

42 MAZZUOLI, Valério de Oliveira; TEIXEIRA, Gustavo de Faria Moreira. O direito internacional do meio ambiente e o greening da convenção americana sobre direitos humanos. Revista Direito GV, São Paulo, v. 1, n. 9, p. 199-242, jan./jun. 2013. p. 221.

43 MAZZUOLI, Valério de Oliveira; TEIXEIRA, Gustavo de Faria Moreira. O direito internacional do meio ambiente e o greening da convenção americana sobre direitos humanos. Revista Direito GV, São Paulo, v. 1, n. 9, p. 199-242, jan./jun. 2013. p. 220. 44 MAZZUOLI, Valério de Oliveira; TEIXEIRA, Gustavo de Faria Moreira. O direito internacional do meio ambiente e o greening da convenção americana sobre direitos humanos. Revista Direito GV, São Paulo, v. 1, n. 9, p. 199-242, jan./jun. 2013. p. 220. 45 MAZZUOLI, Valério de Oliveira; TEIXEIRA, Gustavo de Faria Moreira. O direito internacional do meio ambiente e o greening da convenção americana sobre direitos humanos. Revista Direito GV, São Paulo, v. 1, n. 9, p. 199-242, jan./jun. 2013. p. $221-225$. 
formulado pelos juristas sobre o Direito positivo: a inflação das leis, sua volatidade, sua importância para apreender um mundo decididamente complicado demais, tudo isso faz a lei perder sua majestade e seu valor". O autor ao confirmar a distância entre a lei e o sujeito do direito, define como alternativa uma técnica de normatização dos comportamentos: "A governança é para o governo o que a regulação é para a regulamentação e a ética, para a moral: uma técnica de normatização dos comportamentos que tende a preencher a distância entre a lei e o sujeito de direito." Consiste, pois, em obter comportamento consoante a "ordem estabelecida" ${ }^{46}$.

Com esse raciocínio, exemplifica Supiot, em sua obra Homo juridicus, que é possível, no caso concreto, substituir"uma lógica de controle de aplicação da lei por uma lógica de acompanhamento da realização de um projeto definido conjuntamente". E, vai além, tratando da sanção que é o que confere o caráter coercitivo, e talvez por isso prevalente, à lei: "a ideia de sanção tende então a dissolver-se em mecanismos contratuais de revisão regular dos direitos e obrigações das partes" ${ }^{\prime 47}$.

Eis aqui um horizonte próspero a ser realizado às vistas da regulação acompanhar os patógenos emergentes contaminantes da água, por meio de um projeto definido conjuntamente, em que legislação e princípios ambientais dialoguem e concretizem o direito fundamental à água potável.

Quanto aos limites e possibilidades do diálogo das fontes do direito e/no direito ambiental, especialmente preconizando a potabilidade da água, inerente à sobrevivência e dignidade humana, "no sentido empregado pelo art. 225, caput, do Texto Constitucional, o direito ao meio ambiente ecologicamente equilibrado é um prius lógico do direito à vida"48 e elementarmente a saúde humana, também, possui amparo por corresponder e corroborar com o direito à vida, o que denota que Direitos humanos e meio ambiente estão intimamente ligados, e o texto constitucional, como visto, preconiza ambos. Nesse raciocínio o dialogar das fontes do direito, no caso dos microrganismos que contaminam a água, representa a convergência dos princípios constitucionais ambientais e direitos humanos, em consonância com a legislação. Além disso, corroboram outras fontes bem como o princípio da vedação do retrocesso, que trata que uma nova norma não deva reduzir direitos adquiridos anteriormente, como, por exemplo, no caso das portarias de potabilidade da água, significando que portaria posterior não pode reduzir ou suprimir avanços anteriormente conquistados.

E não é só no Brasil que se faz tal previsão de proteção ambiental e aos direitos humanos de forma conjugada, Mazzuoli traz referências internacionais dessa proteção: No sistema interamericano de direitos humanos, pelo art. 11 do Protocolo Adicional à Convenção Americana sobre Direitos Humanos em Matéria de Direitos Econômicos, Sociais e Culturais (conhecido por Protocolo de San Salvador), de 17.11.1988; No Princípio 1 da Declaração de Estocolmo; No Princípio 10 da Declaração do Rio de Janeiro de 1992; Na Convenção sobre Acesso à Informação, Participação Pública e Acesso à Justiça nas Questões Ambientais (Aarhus, 25.06.1998), destaque-se o preâmbulo: "toda pessoa tem o direito de viver num meio ambiente adequado a sua saúde e bem-estar e o dever, tanto individualmente quanto em associação com outros, de proteger e melhorar o meio ambiente em benefício da geração atual e das gerações futuras"; Na Convenção das Nações Unidas sobre os Direitos da Criança (Nova Iorque, 20.11.1989); Na Carta Africana dos Direitos Humanos e dos Povos (Banjul, 26.06.1991); No art. 27 da Carta dos Direitos Fundamentais da União Europeia; No art. 111 do Tratado para o Estabelecimento da Comunidade da África Oriental ${ }^{49}$.

Tais disposições ilustram o avanço internacional e nacional, haja vista que a Constituição Federal de 1988, "seguindo a tendência do constitucionalismo contemporâneo de se igualar hierarquicamente os tratados de proteção dos direitos humanos às normas constitucionais, deu um grande passo rumo à abertura do sistema

46 SUPIOT, Alain. Homo juridicus: ensaio sobre a função antropológica do direito. São Paulo: WMF M. Fontes, 2007. p. 74-209.

47 SUPIOT, Alain. Homo juridicus: ensaio sobre a função antropológica do direito. São Paulo: WMF M. Fontes, 2007. p. 217-218.

48 MAZZUOLI, Valerio de Oliveira. A proteção internacional dos direitos humanos e o direito internacional do meio ambiente. Revista de Direito Ambiental, v. 34, abr. 2004. p. 97.

49 MAZZUOLI, Valerio de Oliveira. A proteção internacional dos direitos humanos e o direito internacional do meio ambiente. Revista de Direito Ambiental, v. 34, abr. 2004. p. 97. 
jurídico brasileiro ao sistema internacional de proteção de direitos", ao estatuir, no artigo $5^{\circ}, \mathbb{2} 2$. $^{\circ}$ que: "Os direitos e garantias expressos nesta Constituição não excluem outros decorrentes do regime e dos princípios por ela adotados, ou dos tratados internacionais em que a República Federativa do Brasil seja parte" ${ }^{\text {"50 }}$.

Esses tratados internacionais, também, podem representar fonte do direito que podem/devem dialogar com outras fontes em busca da potabilidade da água à medida que preconizem a saúde humana (indubitável aos direitos humanos) no combate aos patógenos emergentes contaminantes da água.

Quanto à mutabilidade/atualização, Supiot discorre que "Menos ainda que a da Lei, aideia de Direitonão poderia ter pretensão à universalidade. Com o Direito, a Lei muda de natureza. De prescrição revelada para sempre num texto imutável, ela se torna um objeto técnico, cujo sentido procede do espírito do Homem que pode criá-la ou reformá-la”. Propõe, em vista do exposto, "a via de um Direito cuja interpretação é realmente aberta", e eventualmente um Tribunal Internacional dos Direitos Humanos, em se tratando de direitos internacionais ${ }^{51}$.

Às vistas de realizar a deserarquização entre as fontes, por sua vez, os princípios acabam tendo salutar relevância, pois, como refere Engelmann, "acabam sendo os responsáveis pela aproximação e relação entre as diversas normas jurídicas", tornando-se o "elo fundamental para a concretização do diálogo entre as fontes" ${ }^{\prime \prime 2}$.

Outra tarefa dos princípios é a de atribuir coerência e consistência, consoante refere Bacovis, reiterando que os princípios possuem papel importante na formação do Direito, oferecendo coerência e a consistência, "dando suporte tanto àquele que produz a norma como àquele que a interpreta" 53 . Assim, "os princípios atuam como inspiração aos legisladores (expressão genérica) e também como apoio aos intérpretes, sendo considerados a verdadeira inteligência das normas em suas duas funções: ordenadora e prospectiva" ${ }^{54}$.

Para tanto, vislumbra-se que a aproximação entre as fontes proporcionada pelos princípios acaba concomitantemente norteando o interprete e o desvencilhando da discricionariedade, haja vista que interpretar "não significa tirar o significado das palavras do texto[...] mas atribuir-lhe sentido" 55 Da mesma maneira, Dworkin revela que "Os juízes devem tomar suas decisões de common law $w^{56}$ embasados em princípios, não em políticas" ${ }^{\prime 5}$.

Para tanto, o resgate ao caso concreto (nesse caso a contaminação microbiológica da água para consumo humano) torna-se condição de possibilidade, sendo necessário, para tanto, recuperar, nas palavras de Stein, o "verdadeiro ambiente" 58 , haja vista o mundo prático ter sido "sequestrado metafisicamente pelas diversas posturas epistemo-metodológicas" ${ }^{\text {" }}$. Ou seja, há necessidade do direito desentranhar-se do puramente

50 MAZZUOLI, Valerio de Oliveira. A proteção internacional dos direitos humanos e o direito internacional do meio ambiente. Revista de Direito Ambiental, v. 34, abr. 2004. p. 97.

51 SUPIOT, Alain. Homo juridicus: ensaio sobre a função antropológica do direito. São Paulo: WMF M. Fontes, 2007. p. 238-268.

52 ENGELMANN, Wilson. As nanotecnologias e os novos direitos: a (necessária) revisão da estrutura das fontes do direito. In: ANUÁRIO DE DERECHO CONSTITUCIONAL LATINOAMERICANO. 17., 2011, Montevideo. p. 383-396. Disponível em: <http://www.juridicas.unam.mx/publica/librev/rev/dconstla/cont/2011/pr/pr25.pdf>. Acesso em: 30 set. 2016.

53 BACOVIS, Maria Cristina M. de Figueiredo. A maturidade das fontes como elemento de consolidação do direito internacional do meio ambiente. Revista de Direito Ambiental, São Paulo, v. 17, n. 66, p. 233-278, jun. 2012.

54 BAPTISTA, Carlos Alberto. A constituição como sistema de princípios e normas. Revista Jurídica Mater Dei, Pato Branco, v. 2 , n. 2, jan./jul. 2002. p. 80.

55 ENGELMANN, Wilson. As nanotecnologias e os novos direitos: a (necessária) revisão da estrutura das fontes do direito. In: ANUÁRIO DE DERECHO CONSTITUCIONAL LATINOAMERICANO. 17., 2011, Montevideo. p. 383-396. Disponível em: <http://www.juridicas.unam.mx/publica/librev/rev/dconstla/cont/2011/pr/pr25.pdf>. Acesso em: 30 set. 2016.

56 Dworkin explica que "Os juristas britânicos e norte-americanos falam da doutrina do precedente; referem-se à doutrina segundo a qual decisões de casos anteriores muito semelhantes a novos casos devem ser repetidas nestes últimos". DWORKIN, Ronald. O império do direito. São Paulo: M. Fontes, 1999. p. 30-31.

57 DWORKIN, Ronald. Law's empire. Londres: Fontana Press, 1986. p. 244.

58 STEIN, Ernildo. Racionalidade e existência: o ambiente hermenêutico e as ciências humanas. Ijuí: Unijuí, 2008. p. 10.

59 STRECK. Lenio Luiz. Verdade e consenso: constituição, hermenêutica e teorias discursivas. da possibilidade à necessidade de respostas corretas em direito. 2. ed. Rio de Janeiro: Lúmen Júris, 2008. p. 5-11. 
formal e ultrapassado, para acompanhar a realidade e as descobertas científicas que contribuam com a sociedade. No caso em tela, utilizando-se do diálogo entre legislação e princípios ambientais para regular os patógenos emergentes que atentem à potabilidade da água.

Resgatando esse "verdadeiro ambiente", promove-se o encontro da verdade e da realidade, qual seja água imprópria para consumo humano diante da desatualizada portaria de potabilidade. Nesse viés, Gadamer refere que "verdade é desocultação" à medida que o "discurso humano não transmite apenas a verdade, mas conhece, também, a aparência, o engano e a simulação", e é exatamente através desse encaminhamento que o diálogo entre as fontes de direito, com salutar papel aos princípios, faz sentido e vem de encontro à interdisciplinaridade e à hermenêutica filosófica ao buscar a resposta correta, tendo, pois, a pretensão de encontrar a verdade, a realidade ${ }^{60}$.

Com efeito, para que o diálogo entre as fontes promova harmonização necessária ao ordenamento entre realidade e regulação, relevante se torna o combate à discricionariedade, desprovida de critérios bem definidos, visto que o intérprete não deve decidir conforme o seu entendimento, mas sim conforme o ordenamento constitucional e as atualizações científicas, restando descabido pois, estabelecer parâmetros de potabilidade da água sem analisar as descobertas científicas e consultar as áreas pertinentes. Assim, também, assevera Freitas: “[...] quanto mais se estiver preocupado com os propósitos ativos da Constituição, menor será o risco de subjetivismo excessivo dos intérpretes [...]"

Para tanto, os verdadeiros sentidos dos princípios têm de serem desvelados e concretizados, sendo pois inadmissível que o intérprete/julgador escolha qual a "melhor" interpretação atribuir aos mesmos, ou a qualquer fonte do Direito, o que corrobora à substituição hierárquica da lei pelo diálogo entre as fontes do direito.

\section{Considerações finais}

A partir do exposto, tornou-se perceptível que o tempo de defasagem entre o processo legislativo e a descoberta de novos patógenos que contaminam a água para consumo humano carece de solução. Também se torna compreensível que a legislação e o processo legislativo não dão conta de toda a problemática que envolve a potabilidade da água e a preservação ambiental.

Destarte, a regulação exerce grande papel quando é de fato concretizada. Sobretudo não se trata meramente da criação de novas leis, o que realmente é constatado é que somente a legislação eficaz e atual tem sentido e razão de existir, pois do contrário se torna inútil.

Para tanto, as fontes do direito devem impreterivelmente acompanhar a ciência, que evolui com o passar dos tempos, e embora se saiba que um tempo de defasagem entre o conhecimento da dinamicidade científica e seu alojamento em Lei seja inevitável, através do diálogo das fontes do direito se torna viável a adaptação ao caso concreto.

A exemplo da Directiva 98/83/CE e da Convenção de Aarhus de 2001, harmonizando tais disposições com os princípios constitucionais brasileiros a fim de suprir a flacidez da legislação (portaria de potabilidade da água), no sentido de concretamente se utilizar de todos os meios para que a água destinada ao consumo humano seja salubre e limpa, ultrapassando, pois os parâmetros momentaneamente estabelecidos, representaria o literal diálogo entre fontes do direito a nível nacional e internacional em vista da concretização do constitucionalmente disposto, como discorrido ao longo do estudo.

Em nível nacional, a portaria de potabilidade (Portaria MS No 2914 de 12 de Dezembro de 2011) deve

60 GADAMER, Hans-Georg. Verdade e método II: complementos e índice. Petrópolis: Vozes, 2002. p. 59-60.

61 FREITAS, Juarez. O controle dos atos administrativos e os principios fundamentais. 4. ed. São Paulo: Malheiros Editores, 2009. p. 33-34. 
concretizar a disposição que trata de revisão de cinco em cinco anos e acrescer, a exemplo da Comunidade Européia, que caso se faça necessário deverá ser revista antes desse período. Mas não é só, efetivamente deve promover o diálogo entre as fontes ao caso concreto quando se verificar a descoberta de algum novo patógeno emergente contaminante da água para consumo humano. Ou seja, deve se valer do direito fundamental à água potável protagonizado pela ONU, dos princípios ambientais constitucionais e do princípio da dignidade da pessoa humana para em cumprimento do disposto no artigo 225 da Constituição Federal conferir potabilidade da água que é um direito fundamental, e para tanto deverá, sob tais argumentos, fazer uso imediato das técnicas (tecnologias) possíveis para inibir a contaminação, até que a portaria seja atualizada, já que o tempo de defasagem entre a descoberta científica e a regulação (atualização da portaria) é inevitável, uma vez que não há como se legislar sobre o futuro.

Para tanto há de se utilizar da interdisciplinariedade, onde ciência, tecnologia e direito unam esforços no acontecer constitucional, aqui especificamente em busca da potabilidade da água. Do contrário ou se permanecerá num faz de conta, onde se acredite que a portaria de potabilidade contempla todos os patógenos e assim todos possuem água potável ao abrir as torneiras de suas residências ou então se transferirá ao Judiciário a questão que decidirá discricionariamente, frente à flacidez/lacuna legislativa.

Todas essas questões revelam que, além de valorar devidamente o texto Constitucional, em se tratando de deserarquização das fontes do direito, a preservação da natureza e a saúde pública não possuem menos importância do que qualquer outro tema, haja vista se tratar de previsões expressas na Constituição Federal em vigor, em legislações esparsas e nos tratados e acordos internacionais da ONU dos quais o Brasil é signatário, que por si só já denomina pressuposto e condição de possibilidade de quaisquer outras discussões.

Isto posto, especificamente tratando do problema da legislação frente aos patógenos emergentes contaminantes da água para consumo humano, se fosse observado somente o caráter normativo, regulatório da questão, ter-se-ia como primordial, em qualquer situação, a iminente e imperativa observância dos avanços científicos para garantir a potabilidade da água, ordenando aos abastecedores que fizessem uso das técnicas e tecnologias necessárias para combater os novos contaminantes, até que nova portaria (mera formalidade) fosse aprovada, a exemplo da União Europeia, contudo, o que se observa são os empecilhos políticos e de gestão (ineficiência e falta de fiscalização), que contaminam a esfera jurídica e os três poderes, legislativo, executivo e judiciário, tornando todo o sistema inoperante baseado na política de interesses.

Por isso e em vista da necessidade de adaptar os avanços científicos às formas de regulação da sociedade (fontes do direito), o diálogo entre as fontes do direito pode representar uma viável, talvez única, alternativa de harmonização entre realidade e regulação.

\section{REFERÊNCIAS BIBLIOGRÁFICAS}

AGÊNCIA NACIONAL DE ÁGUAS. Programa das Nações Unidas para o Meio Ambiente. Cuidando das águas: soluções para melhorar a qualidade dos recursos hídricos. Brasília: ANA, 2011.

AMARAL JÚNIOR, Alberto do. O diálogo das fontes: fragmentação e coerência no direito internacional contemporâneo. Anuário Brasileiro de Direito Internacional, v. 2, 2008.

BACOVIS, Maria Cristina M. de Figueiredo. A maturidade das fontes como elemento de consolidação do direito internacional do meio ambiente. Revista de Direito Ambiental, São Paulo, v. 17, n. 66, p. 233-278, jun. 2012.

BAPTISTA, Carlos Alberto. A constituição como sistema de princípios e normas. Revista Jurídica Mater Dei, Pato Branco, v. 2, n. 2, jan./jul. 2002.

BINENBOJM, Gustavo. Uma teoria do direito administrativo: direitos fundamentais, democracia e constitucio- 
nalização. 2. ed. Rio de Janeiro: Renovar, 2008.

BOBBIO, Norberto. Teoria do ordenamento jurídico. São Paulo: Edipro, 2011.

CARVALHO, José Maurício. Miguel Reale: ética e filosofia do direito. Porto Alegre: EDIPUCRS, 2011.

DWORKIN, Ronald. Law's empire. Londres: Fontana Press, 1986.

DWORKIN, Ronald. O império do direito. São Paulo: M. Fontes, 1999.

ENGELMANN, Wilson. As nanotecnologias e os novos direitos: a (necessária) revisão da estrutura das fontes do direito. In: ANUÁRIO DE DERECHO CONSTITUCIONAL LATINOAMERICANO. 17., 2011, Montevideo. p. 383-396. Disponível em: < http://www.juridicas.unam.mx/publica/librev/rev/dconstla/cont/2011/pr/pr25.pdf>. Acesso em: 30 set. 2016.

ENGELMANN, Wilson; HOHENDORFF, Raquel Von. De Eric Drexler a Erik Jayme: as respostas que o direito (ainda não) tem para a questão das nanotecnologias. In: ROVER, Aires Josér; SIMÃO FILHO, Adalberto; PINHEIRO, Rosalice Fidalgo (Org.). Direito e Novas Tecnologias. Florianópolis: FUNJAB, 2013. v. 1. p. 362-391.

FREITAS, Juarez. O controle dos atos administrativos e os princípios fundamentais. 4. ed. São Paulo: Malheiros Editores, 2009.

GADAMER, Hans-Georg. Verdade e método II: complementos e índice. Petrópolis: Vozes, 2002.

GADAMER, Hans-Georg. Verdade e método: traços fundamentais de uma hermenêutica filosófica. 3. ed. Petrópolis: Vozes, 1999.

HUPFFER, Haide Maria et al. A flacidez da legislação brasileira em relação aos patógenos emergentes. Revista de Direito Ambiental, v. 69, p. 315-342, jan./mar. 2013.

JAYME, Erik. Identité culturelle et intégration: le droit international privé postmoderne. Recueil des Cours de l'Académie de Droit International de la Haye, II, Kluwer. Haia, 1995.

JAYME, Erik. Visões para uma teoria pós-moderna do direito comparado. Revista dos Tribunais, v. 759, jan. 1999.

LUZ, Cícero Krupp da. Governança, déficit democrático e processo legislativo europeu. Revista Direitos Culturais, Santo Ângelo, v. 8, n. 16, 2013.

MARQUES, Cláudia Lima. Superação das antinomias pelo diálogo das Fontes: o modelo brasileiro de coexistência entre o código de defesa do consumidor e o código civil de 2002. Revista Da ESMESE, Aracajú, n. 7, 2004.

MAZZUOLI, Valerio de Oliveira. A proteção internacional dos direitos humanos e o direito internacional do meio ambiente. Revista de Direito Ambiental, v. 34, p. 97, abr. 2004.

MAZZUOLI, Valério de Oliveira; TEIXEIRA, Gustavo de Faria Moreira. O direito internacional do meio ambiente e o greening da convenção americana sobre direitos humanos. Revista Direito GV, São Paulo, v. 1, n. 9, p. 199-242, jan./jun. 2013.

NARASIMHAN, T. N. Water, Law, Science. Journal of Hydrology. Science Direct. Department of Materials Science and Engineering, and Department of Environmental Science, Policy and Management, University of California at Berkeley, p. 125-138, Oct. 2007.

ORGANIZAÇÃO DAS NAÇÕES UNIDAS PARA A EDUCAÇÃO, A CIÊNCIA E A CULTURA -UNESCO. Gestão mais sustentável da água é urgente. Disponível em: <http://www.unesco.org/new/pt/brasilia/about-this-office/single-view/news/urgent_need_to_manage_water_more_sustainably_says_un_report/\#.Vh6lUdLwvct>. Acesso em: 14 set. 2016. 
PÉREZ LUÑO, Antonio Henrique. El desdobramiento de las fuentes del derecho. Madrid: La Ley, 2011.

PESSANHA, Charles. O poder executivo e o processo legislativo nas constituições brasileiras: teoria e prática. In: VIANA, Luiz Werneck. A democracia e os três Poderes no Brasil. Rio de Janeiro: IUPERJ/FAPERJ, 2002.

SANTOS, Boaventura de Souza. Linha do Horizonte. In: SANTOS, Boaventura de Souza (Org.). A Globalização e as Ciências Sociais. 2. ed. São Paulo: Cortez, 2002. p. 70.

SARLET, Ingo Wolfgang; FENSTERSEIFER, Tiago. Direito constitucional ambiental: estudos sobre a constituição, os direitos fundamentais e a proteção do ambiente. São Paulo: Revista dos Tribunais, 2011.

SILVA, Ovídio Araújo Baptista da. Jurisdição e execução na tradição romano-canônica. 2. ed. São Paulo: Revista dos Tribunais, 1997.

STEIN, Ennildo. Racionalidade e existência: o ambiente hermenêutico e as ciências humanas. Ijuí: Unijuí, 2008.

STRECK, Lenio Luiz. Da interpretação de textos à concretização de direitos: o desafio da hermenêutica comprometida com o Estado democrático de direito. Revista Latino-americana de Estudos Constitucionais, v. 6, jul./dez. 2015.

STRECK, Lenio Luiz. Devemos nos importar, sim, com o que a doutrina diq? 2006. Disponível em: <http://www. conjur.com.br/2006-jan-05/devemos_importar_sim_doutrina>. Acesso em: 19 set. 2016.

STRECK, Lenio Luiz. Verdade e consenso: constituição, hermenêutica e teorias discursivas: da possibilidade à necessidade de respostas corretas no direito. 3. ed. Rio de Janeiro: Lumen Juris, 2009.

SUPIOT, Alain. Homo juridicus: ensaio sobre a função antropológica do direito. São Paulo: WMF M. Fontes, 2007.

ZAGREBELSKY, Gustavo. El derecho dúctil: ley, derechos, justicia. Madrid: Editorial Trotta, 2009. 
Para publicar na revista Brasileira de Políticas Públicas, acesse o endereço eletrônico www.rbpp.uniceub.br

Observe as normas de publicação, para facilitar e agilizar o trabalho de edição. 